AnNA SOBCZAK

ORCID 0000-0002-6174-9045

Uniwersytet im. Adama Mickiewicza

$w$ Poznaniu

\title{
(RE)KONSTRUKCJA KRYTERIÓW PRZYJMOWANIA DO PRACY \\ W WARUNKACH NEOLIBERALNEGO SPOŁECZEŃSTWA
}

\begin{abstract}
AвSTRACt. Sobczak Anna, (Re)konstrukcja kryteriów przyjmowania do pracy w warunkach neoliberalnego społeczeństwa [(Re)construction of the Criteria for Hiring in the Neoliberal Society Conditions]. Studia Edukacyjne nr 52, 2019, Poznań 2019, pp. 213-226. Adam Mickiewicz University Press. ISSN 12336688. DOI: $10.14746 /$ se.2019.52.14
\end{abstract}

The aim of the article is to indicate the criteria for hiring in the current neoliberal society and the requirements of modern employers towards people applying for employment. The text discusses the main assumptions of neoliberal ideology in the context of the functioning of individuals in the labor market and their careers. The notions of academic diploma inflation and overeducation are also defined. The article indicates that today in many cases formal qualifications are an absolute minimum in the recruitment process, and for employers, apart from formal credentials, crucial are the behavioural and personality aspects of potential candidates.

Key words: neoliberal society, overeducation, academic diploma inflation, labor market, recruitment process, career

W ostatnich dekadach w życiu społeczno-kulturowym oraz ekonomicznym współczesnych społeczeństw zaszło wiele zmian. W znaczący sposób wpłynęły one na funkcjonowanie rynku pracy, w tym na zapotrzebowanie pracodawców na odpowiednie kadry, co wiąże się z określonymi wymaganiami wobec potencjalnych kandydatów do pracy. Bez wątpienia, poszukujących dziś zatrudnienia jednostek legitymizujących się wyższym wykształceniem, w tym obecnych absolwentów szkół wyższych „obowiązują" inne, zmienione lub całkowicie „nowe” kryteria przyjmowania do pracy, niż to miało miejsce $\mathrm{w}$ przeszłości. Związane jest to między innymi z neoliberalną polityką 
społeczną, jak również ze zjawiskiem inflacji dyplomu akademickiego oraz przeedukowania społeczeństwa, które wpłynęły na zwiększoną rywalizację na rynku pracy, w szczególności w segmencie międzynarodowych korporacji postrzeganych jako instytucje oferujące atrakcyjne, dobrze płatne miejsca pracy z szansą na awans zawodowy. Nie bez powodu w ostatnich czasach powstało szereg poradników oraz artykułów dotyczących "przetrwania” lub też odniesienia sukcesu w środowisku korporacyjnym ${ }^{1}$. W tym kontekście mówi się również o swoistym „wyścigu szczurów”, a także pojawiły się takie określenia, jak „,korpoludki”, ",trybiki”, czy „,korposzczury” odnoszące się do sytuacji zawodowej pracowników zatrudnionych w korporacjach².

Obecnie obserwuje się rosnącą rolę czynników psychologicznych oraz tak zwanych kompetencji miękkich w osiąganiu sukcesu zawodowego w warunkach korporacyjnej rywalizacji i znacznej liczby absolwentów szkół wyższych, która każdego roku opuszcza mury uniwersytetów. Za Zbyszko Melosikiem wskazać należy, iż nadwyżka osób legitymujących się dyplomem ukończenia szkoły wyższej i znakomitymi kwalifikacjami spowodowała zmianę kryteriów, którymi kierują się pracodawcy w procesie poszukiwania nowych pracowników ${ }^{3}$. Współcześnie wyższe wykształcenie i uzyskane $\mathrm{w}$ procesie edukacji na studiach wyższych kwalifikacje postrzegane są przez pracodawców jedynie jako swoisty "punkt wyjściowy". Dyplom ukończenia studiów i kwalifikacje z nim związane przestały być kryterium „wyróżniającym”. Akademicki kredencjał nie stanowi więc już decydującego kryterium wyboru danego kandydata do pracy w procesie rekrutacji. Celem mojego artykułu jest wskazanie obecnych kryteriów przyjmowania do pracy oraz wymagań współczesnych pracodawców wobec osób ubiegających się o zatrudnienie.

Zanim jednak przejdę do analizy oczekiwań pracodawców, nakreślę zasady funkcjonowania neoliberalnych społeczeństw w interesującym mnie kontekście, jak również zdefiniuję pojęcia inflacji dyplomu akademickiego oraz przeedukowania, które stanowią jeden z głównych społeczno-edukacyjnych problemów postindustrialnych wysoko rozwiniętych cywilizacji.

${ }^{1}$ Por. m.in. J. Kisińska, Homo corporaticus, czyli przewodnik przetrwania w korporacji, https:/ / onepress.pl/ksiazki/homo-corporaticus-czyli-przewodnik-przetrwania-w-korporacji-joanna-krysinska,jaszko.htm\#format/e [dostęp: 08.04.2019]; K. Tamondong, Surviving The Corporate Jungle: 8 Unwritten Rules To Guide Your Success, 2014, https://www.elitedaily.com/money/ surviving-the-corporate-jungle-8-unwritten-rules-to-guide-your-success [dostęp: 08.04.2019]; D. Maikowski, Jak okiełznać „Mordor”? 12 zasad przetrwania w korporacji, https:/ / praca.interia.pl/ news-jak-okielznac-mordor-12-zasad-przetrwania-w korporacji,nId,1671792\#utm_source=paste\&utm_medium=paste\&utm_campaign=chrome, 2015 [dostęp: 08.04.2019].

2 Por. m.in. M. Grodziński, Korposzczury, prawdziwi wyklęci, 2016, http:/ / wyborcza.pl/magazyn/1,124059,19886789,korposzczury-prawdziwi-wykleci.html [dostęp: 08.04.2019].

${ }_{3}^{3}$ Z. Melosik, Uniwersytet i społeczeństwo. Dyskursy wolności, wiedzy i władzy, Kraków 2009, s. 137. 
Andrzej Rozmus odwołując się do słów Michela Foucaulta stwierdza, iż

neoliberalizm tworzy społeczeństwo nowego typu, które zostawia margines swobody jednostkom i nie wpływa bezpośrednio na uczestników gry, lecz jedynie na reguły tej gry ${ }^{4}$.

Odnosząc się do kwestii funkcjonowania na rynku pracy i kariery, idea neoliberalnego społeczeństwa zakłada, że jednostka jest w pełni odpowiedzialna za swój los oraz sukces społeczny, jak również zawodowy lub niepowodzenie w tym zakresie. Każdy z osobna musi zatem efektywnie realizować swoją wolność, kreować własną tożsamość, a także zadbać o odpowiednią pozycję w społecznej hierarchii ${ }^{5}$. Związane jest to z jednymi z głównych idei neoliberalizmu, jakimi są wolność oraz indywidualizm jednostek, które mają kierować swoim życiem ${ }^{6}$. Warto podkreślić, za Agnieszką Gromkowską-Melosik, że neoliberalizm kreuje

wizję człowieka, który pozbawiony wewnętrznych problemów, zdolny do samoregulacji, pnie się na szczyt drabiny społecznej, uznając porażkę za przejaw swojej nieadekwatności (w jednostki internalizuje się przekonanie: „mogę być kim chcę, a jeśli mi się nie uda, to znaczy, że jestem beznadziejny").

Autorka wskazuje, że ideologia neoliberalizmu bagatelizuje znaczenie społecznych nierówności, a jednostki „mają «maniakalnie» walczyć o suk-

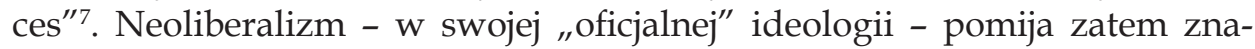
czenie pochodzenia społecznego, a jego jedną z głównych przesłanek jest walka o sukces ${ }^{8}$ między innymi poprzez ciągłe udoskonalanie siebie. Warto zaznaczyć, iż wskutek tego młodzież nie posiada zwykle świadomości znaczenia takich strukturalnych czynników jak płeć, pochodzenie oraz rasa, które $\mathrm{w}$ praktyce mają wciąż ważne znaczenie w decydowaniu o społecznych możliwościach jednostek ${ }^{9}$.

Współcześnie od wczesnego dzieciństwa ludzie pod wpływem neoliberalnego podejścia są socjalizowani do ciągłej rywalizacji oraz zdobywania kolejnych osiągnięć zarówno w sferze prywatnej, edukacyjnej, jak i zawodowej. Potwierdzeniem tego mogą być słowa Zbyszko Melosika, który zauważa, że

${ }^{4}$ M. Foucault, The British of biopolitics. Lectures at the callege de France 1978-1979, New York podaję za: A. Rozmus, Edukacja akademicka w perspektywie krytycznej. Studenci wobec neoliberalnej polityki kształcenia w szkole wyższej, Kraków - Rzeszów 2018, s. 77.

${ }^{5}$ Z. Melosik, Kultura popularna i tożsamość młodzieży. W niewoli władzy i wolności, Kraków 2013, s. 313.

${ }^{6}$ A. Rozmus, Edukacja akademicka, s. 78.

7 A. Gromkowska-Melosik, Edukacja i nierówność społeczna kobiet. Studium dynamiki dostępu, Kraków 2011, s. 146.

8 Tamże, s. 143-146.

9 Z. Melosik, Kultura popularna, s. 313. 
w społeczeństwie neoliberalnym biografia i tożsamość jednostki podporządkowane są idei rywalizacji o sukces, idei podziału na zwycięzców i "całą resztę", a zaznaczyć trzeba przy tym, iż zwycięstwo nie oznacza, że jest się na mecie, stanowi ono punkt wyjścia następnego wyścigu czy następnej gry ${ }^{10}$.

Wskazać zatem należy, że neoliberalne zasady zwiększają konkurencję, a tym samym zaostrzają rywalizację na rynku pracy pomiędzy jednostkami $\mathrm{w}$ walce o najlepsze i dobrze płatne stanowiska pracy, które obsadzane są przez pracodawców według innych, często bardziej „rygorystycznych”, a często wręcz odwrotnie „rozmytych” kryteriów niż to miało miejsce w przeszłości.

Podkreślić raz jeszcze trzeba, iż neoliberalna jednostka w założeniu powinna zdobywać coraz to wyższe szczeble edukacji, a następnie wspinać się po zawodowej drabinie, aby znaleźć się na samym jej szczycie. Współcześnie przy tym w wielu rozwiniętych społeczeństwach występuje znaczna nadpodaż osób legitymujących się wyższym wykształceniem w stosunku do potrzeb rynku pracy, co spowodowało drastyczny spadek wartości dyplomu akademickiego. Sytuacja ta jest skutkiem zwiększonych aspiracji jednostek wynikających z dążenia do osiągnięcia sukcesu społeczno-zawodowego. Związana jest ona także $z$ demokratyzacją edukacji, zwłaszcza na poziomie szkolnictwa wyższego, która miała miejsce w ostatnich dekadach, wpływając tym samym na zwiększenie dostępu do kształcenia akademickiego grupom wcześniej dyskryminowanym (kobietom, osobom pochodzącym z niższych klas społecznych, mniejszościom rasowym oraz etnicznym). Obecnie mamy do czynienia z coraz większą dysproporcją pomiędzy aspiracjami jednostek, które zostały rozbudzone przez system edukacyjny, a benefitami wynikającymi z posiadania formalnych kredencjałów. Dyplom akademicki nie jest już gwarancją powodzenia na rynku pracy ${ }^{11}$. Należy wskazać, że problem ten nie dotyczy jedynie dyplomów uzyskiwanych na poziomie licencjackim oraz magisterskim, ale także dyplomów studiów doktoranckich, które w ostatnich latach również uległy umasowieniu. Jak zauważa Katarzyna Martkowska oraz Mateusz Molasy:

O ile kiedyś przed absolwentem studiów trzeciego stopnia kształcenia rysowała się kariera akademicka, o tyle od pewnego czasu uczelnie nie są w stanie wchłaniać lawinowo rosnącej liczby młodych doktorów ${ }^{12}$.

W swojej definicji „inflacji dyplomu” klasyk socjologii edukacji Pierre Bourdieu pisze $\mathrm{w}$ sposób prosty, że jest ona związana $\mathrm{z}$ „rozbieżnością mię-

10 Tamże, s. 323-325.

11 Z. Melosik, Uniwersytet i społeczeństwo, s. 137.

${ }_{12}$ K. Martkowska, M. Molasy, Spoteczna odpowiedzialność uczelni w procesie ksztatcenia przysztych elit, [w:] Społeczna odpowiedzialność uczelni, red. K. Leja, Gdańsk 2008, s. 100. 
dzy aspiracjami, które system edukacyjny wytwarza, a możliwościami, które w rzeczywistości oferuje ${ }^{\prime 13}$. W jego książce pojawia się także pojęcie „inflacji” czy „dewaluacji” kwalifikacji, które w takich warunkach odczuwają absolwenci $^{14}$. W mikroskali odnosi się to do niewykorzystania uzyskanego dyplomu na rynku pracy, a w makroskali - braku możliwości przyczyniania się do rozwoju ekonomicznego państwa. Lei Delsen twierdzi, że inflacja dyplomu pojawia się wówczas, kiedy „nie jest już możliwe uzyskanie dzięki niemu tak wysokiej pozycji na rynku pracy po ukończeniu edukacji, jak to miało miejsce z tym samym dyplomem w przeszłości"15. Podobnie, A.P. Marques pisze, że inflacja dyplomu odnosi się do „relatywnej deprecjacji” posiadanego wykształcenia $^{16}$.

Z kolei, przeedukowanie społeczeństwa, stanowiące jedną z głównych przyczyn inflacji dyplomu akademickiego, dotyczy sytuacji, w której nie występuje korelacja pomiędzy istniejącą strukturą zawodową oraz potrzebami rynku pracy a strukturą absolwentów szkół wyższych ${ }^{17}$. Koji Ueno i Alexandra Krause definiują więc pojęcie przeedukowania (ang. overeducation) jako „formę niedopasowania edukacji i zawodu, która reprezentuje nadmiar wykształcenia dla konkretnego zawodu"18. Natomiast, Séamus McGuinness wyjaśnia, że przeedukowanie oznacza „stopień, w jakim wykształcenie danej osoby wykracza poza to, co jest wymagane do wykonywania określonej pracy"19.

Obecnie więc, uwzględniając ekonomiczne i strukturalne uwarunkowania rynku pracy, mamy do czynienia z nadwyżką absolwentów - liczba osób z dyplomem szkoły wyższej przewyższa zapotrzebowanie społeczeństwa w tym zakresie, co skutkuje jego inflacją, a także powoduje, że część osób zmuszona jest do podjęcia pracy poniżej swoich kwalifikacji oraz formalnych kredencjałów. Zbyszko Melosik zauważa, że utrzymanie równowagi pod tym względem byłoby możliwe poprzez ograniczenie liczby osób przyjmowanych na uniwersytety, ale sprzeczne z ideą powszechnej edukacji wyższej $^{20}$ (i demokratyzacji życia społecznego). Natomiast, raz jeszcze podkreślić trzeba za Jolantą M. Szaban, że

\footnotetext{
${ }^{13}$ P. Bourdieu, Distinction: A Social Critique of the Judgement of Taste, Cambridge 1984, s. 143.

${ }^{14}$ Tamże, s. 142.

${ }^{15}$ L. Delsen, Exit Polder Model?: Socioeconomic Changes in the Netherlands, Westport 2002, s. 55 .

${ }^{16}$ A.P. Marques, Unequal Itineraries for Graduates: A Typology of Entrance into Labour Market, Academic Journal of Interdisciplinary Studies, 2015, 4 (1S2), s. 21.

17 Z. Melosik, Uniwersytet i społeczeństwo, s. 135.

${ }_{18} \mathrm{~K}$. Ueno, A. Krause, Overeducation, perceived career progress, and work satisfaction in young adulthood, Research in Social Stratification and Mobility, 2018, 55, s. 51.

${ }^{19}$ S. McGuinness, Overeducation in the Labour Market, Journal of Economic Surveys, 2006, 20(3), s. 387.

${ }^{20}$ Tamże, s. 136.
} 
współczesna „nadprodukcja” magistrów spowodowała dewaluację wartości, jaką ongiś dyplom zapewniał, bowiem co oczywiste, ilość nigdy nie przechodzi w jakość ${ }^{21}$.

Dyplom ukończenia uczelni wyższej nie ma zatem już tak dużego znaczenia i wartości, jak to miało miejsce w przeszłości, czego potwierdzeniem są słowa Henryka Domańskiego, który wskazuje, że

wyższe wykształcenie przestało być (...) atrybutem zapewniającym dostęp do lukratywnych pozycji zawodowych, o wysokim statusie społecznym²2.

Bez wątpienia, zjawisko inflacji dyplomu akademickiego oraz przeedukowania społeczeństwa zwiększyło rywalizację na rynku pracy pomiędzy jednostkami, głównie posiadającymi dyplom ukończenia szkoły wyższej. Zjawiska te przyczyniły się również do wzrastających oczekiwań pracodawców względem absolwentów szkół wyższych, a także „przedefiniowało” proces selekcji oraz rekrutacji pracowników, w którym pojawiły się nowe kryteria przyjmowania do pracy lub zmieniła się rola dotychczasowych poszczególnych kryteriów rekrutacji personelu. Obecnie więc pracodawcy wymagają od pracownika nie tylko wypełniania swoich obowiązków zawodowych związanych z zajmowanym stanowiskiem pracy, lecz ważna jest dla nich także odpowiednia postawa zatrudnionego wobec pracy, zaangażowanie w wykonywane zadania służbowe, a także umiejętność pracy zespołowej ${ }^{23}$, która jest niezwykle pożądana na współczesnym rynku pracy.

W miejscu tym należy przedstawić, za Haliną Sobocką-Szczapą, cztery główne grupy kryteriów doboru pracowników ${ }^{24}$. Pierwszą są kryteria kwalifikacyjne, które odnoszą się do umiejętności umożliwiających pełnienie pewnej roli organizacyjnej, między innymi takich jak: doświadczenie zawodowe, wykształcenie, znajomość obsługi komputera, czy umiejętności posługiwania się językami obcymi. Kolejne kryteria doboru pracowników to tak zwane kryteria efektywnościowe, oznaczające terminowość, wydajność, jakość pracy, czy też skuteczność działania. Należy jednak zaznaczyć, iż odgrywają one większą rolę podczas procesu oceny obecnych już pracowników niż podczas procesu rekrutacji. Z kolei, trzecią grupę wskaźników doboru pracowników stanowią kryteria behawioralne dotyczące sposobu zachowania wymaganego na danym stanowisku pracy, o które ubiegają się potencjalni kandydaci.

${ }^{21}$ J.M. Szaban, Rynek pracy w Polsce i w Unii Europejskiej, Warszawa 2016, s. 216.

${ }^{22}$ H. Domański, Stratyfikacja a system społeczny w Polsce, Ruch Prawniczy, Ekonomiczny i Socjologiczny, 2009, 2, s. 386.

23 Ecorys, Absolwent na rynku pracy - poradnik dla Ucznia i Nauczyciela, s. 55, https:// ckziunr3.pl/wp-content/uploads/KCDZ/doradz15.pdf [dostęp: 09.04.2019].

${ }^{24}$ H. Sobocka-Szczapa, Dobór pracowników - decyzja strategiczna firmy, Zeszyty Naukowe Politechniki Śląskiej, 2014, 1905, s. 110 (Autorka wykorzystuje klasyfikację przyjmowaną do oceny pracowników w procesie pracy). 
Wśród nich należy wymienić między innymi umiejętność prowadzenia rozmowy z klientami, komunikatywność, czy też znajomość określonych przepisów. Jak wskazuje Halina Sobocka-Szczapa, "stosowanie behawioralnych kryteriów oceny jest konsekwencją założenia, że istnieje związek między jakością i efektywnością pracy a postawami pracowników"25. Ostatnimi już kryteriami są kryteria osobowościowe, do których zaliczają się cechy charakterologiczne oraz intelektualne potencjalnego kandydata do pracy. Wykorzystując te właśnie kryteria, pracodawca ocenia odporność na stres, emocjonalność, otwartość w relacjach międzyludzkich, wrażliwość, poziom inteligencji, jak również kulturę osobistą ${ }^{26}$.

Niewątpliwie, dobór poszczególnych kryteriów przez pracodawców uzależniony jest od konkretnego stanowiska pracy, jednak we współczesnym neoliberalnym społeczeństwie, charakteryzującym się nadpodażą osób z wyższym wykształceniem i co za tym idzie - dużym stopniem rywalizacji, w wielu przypadkach coraz częściej kryteria behawioralne oraz osobowościowe odgrywają w rekrutacji znaczącą, a niejednokrotnie nawet decydującą rolę. Jak słusznie wskazuje Jolanta M. Szaban, „W zalewie magistrów trudno wyłowić rzeczywiste talenty" ${ }^{27}$, dlatego pracodawcy nie bazują już jedynie na samych formalnych kwalifikacjach potencjalnych kandydatów do pracy, a szukają innych bardziej skuteczniejszych metod selekcji najlepszych z nich, szczególnie kiedy osoby ubiegające się o zatrudnienie mają takie same lub bardzo zbliżone kwalifikacje formalne, co w obecnej sytuacji przeedukowania jest zjawiskiem niemal powszechnym. Na brak zaufania do jakości oraz „prawomocności” współczesnych dyplomów akademickich, a co za tym idzie - posiadanych kwalifikacji przez absolwentów szkół wyższych, wskazuje Anna Kokocińska, która na podstawie przeprowadzonych przez siebie badań jakościowych wśród pracodawców dotyczących wartości wyższego wykształcenia stwierdza, iż

Do wykształcenia u młodych ludzi „właściwych” postaw na pewno nie przyczyniają się według pracodawców i kadrowych studia wyższe, które w obecnym systemie nie niosą ze sobą odpowiednich wartości. Dziś uzyskanie dyplomu nie stanowi żadnej trudności, panuje przekonanie, że wyższe wykształcenie można kupićé ${ }^{28}$.

Stąd, coraz częściej pracodawcy podczas procesu doboru pracowników kierują się dodatkowymi, prócz formalnych kwalifikacji, kryteriami oceny kapitału ludzkiego, jaki reprezentują potencjalni kandydaci do pracy. Jak możemy przeczytać w jednym z dokumentów międzynarodowej firmy kon-

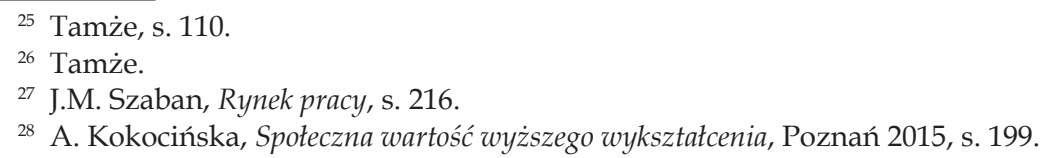


sultingowo-badawczej Ecorys, dotyczącym funkcjonowania absolwentów na rynku pracy w dzisiejszych czasach, „wysokie kwalifikacje, jakkolwiek ważne i bardzo znaczące, już nie wystarczą, by sprostać wymaganiom rynku pracy" ${ }^{29}$, których wzrost związany jest z przeobrażeniami technologiczny$\mathrm{mi}$, gospodarczymi oraz społecznymi mającymi miejsce $\mathrm{w}$ ostatnim czasie ${ }^{30}$. Podkreślono również, iż oczekiwania pracodawców wobec potencjalnych kandydatów do pracy są wysokie, o czym świadczy fakt, iż od zatrudnianych osób oczekują oni wszechstronnych kompetencji, elementami składowymi których są umiejętności, zdobyta wiedza oraz postawy ${ }^{31}$. Także Agnieszka Knap-Stefaniuk zauważa, iż „Z roku na rok wymagania pracodawców rosną, a ich lista poszerza się o kolejne kompetencje"32.

Współcześnie duże znaczenie oprócz posiadanego wykształcenia mają tak zwane kompetencje miękkie ${ }^{33}$, określane także jako kompetencje interpersonalne, społeczne, psychospołeczne, czy ponaddyscyplinarne ${ }^{34}$, do których zalicza się umiejętność pracy w grupie, komunikatywność, radzenie sobie z problemami, umiejętność organizacji pracy i zarządzania czasem, kreatywność, umiejętność szybkiego reagowania na zmiany oraz wyjątkowo ważna - umiejętność motywowania się do pracy ${ }^{35}$, a także cechy charakterologiczne kandydata, takie jak uczciwość, lojalność, odpowiedzialność, czy też odporność na stres. Te atrybuty ludzi są niezależne jakby od kwalifikacji i odwołują się do współczesnej neoliberalnej wizji jednostki odpowiedzialnej za swoją tożsamość. Wymienione wyżej wymagania potwierdzają liczne badania na temat oczekiwań wobec przyszłych pracowników przeprowadzane z udziałem pracodawców.

Warto odwołać się do wyników badań ankietowych przeprowadzonych przez Szkołę Główną Handlową w Warszawie, Amerykańską Izbę Handlu w Polsce oraz organizację Ernst \& Young w 2012 roku dotyczących kompetencji oraz kwalifikacji poszukiwanych przez pracodawców wśród absolwentów szkół wyższych wchodzących na rynek pracy. W raporcie z tychże badań, w których udział wzięły 53 firmy, wskazano, iż to właśnie kompetencje osobiste oraz interpersonalne są najczęściej wskazywane jako kryterium wykorzystywane przez pracodawców podczas rekrutacji absolwentów szkół

29 Ecorys, Absolwent na rynku pracy, s. 55, [dostęp: 09.042019].

30 A. Knap-Stefaniuk, Wspótczesny rynek pracy - oczekiwania pracodawców w zakresie kompetencji kandydatów, [w:] Człowiek wobec wyzwań wspótczesnego rynku pracy, red. S. Ciupka, A. Knap-Stefaniuk, A. Sapiński, Kraków 2015, s. 23.

31 Ecorys, Absolwent na rynku pracy, s. 55, [dostęp: 09.042019].

32 A. Knap-Stefaniuk, Współczesny rynek pracy, s. 23.

33 Ecorys, Absolwent na rynku pracy, s. 55, [dostęp: 09.042019].

34 H. Sobocka-Szczapa, Zarządzanie kompetencjami pracowników a kapitat intelektualny organizacji, Prace Naukowe Uniwersytetu Ekonomicznego we Wrocławiu, 2017, s. 111-112.

35 Ecorys, Absolwent na rynku pracy, s. 55, [dostęp: 09.042019]. 
wyższych. Wymieniło je co trzecie badane przedsiębiorstwo. Na przeciwległym biegunie znalazło się kryterium dotyczące wysokości oceny na dyplomie ukończenia studiów (jedynie 2\% wskazań). Także kierunek studiów i poziom uzyskanego wykształcenia wyższego - studia licencjackie czy magisterskie nie mają dużego znaczenia dla pracodawców - jedynie po 7\% badanych firm wskazało na istotność tych dwóch aspektów w procesie wyłaniania i zatrudniania pracowników ${ }^{36}$. W dokumencie, na podstawie odpowiedzi respondentów na postawione pytanie otwarte, które dotyczyło kompetencji „idealnego" absolwenta, stworzono również ranking najbardziej pożądanych umiejętności. Na samym jego szczycie znalazły się kolejno: efektywna komunikacja, otwartość na uczenie się i stały rozwój, aktywność i zaangażowanie w pracy, a także elastyczność i zdolność do adaptacji. Zaznaczyć przy tym trzeba, iż wiedza branżowa oraz umiejętności analityczne wskazywane były przez pracodawców znacznie rzadziej ${ }^{37}$. W wymienionych wyżej przypadkach zakładano zapewne, że są to atrybuty niejako „wyjściowe”, posiadane przez wszystkie osoby.

Również raport zatytułowany „Rynek pracy widziany oczami pracodawców", przedstawiający wyniki badań pracodawców i ofert pracy przeprowadzonych w 2014 roku w ramach V edycji projektu Bilans Kapitału Ludzkiego (we wszystkich pięciu edycjach łącznie przebadano 80018 pracodawców), realizowanego wspólnie przez Polską Agencję Rozwoju Przedsiębiorczości i Uniwersytet Jagielloński (Centrum Ewaluacji i Analiz Polityk Publicznych), potwierdza, iż dla pracodawców poszukujących pracowników jednymi z najistotniejszych kompetencji są kompetencje interpersonalne. Jak napisano $\mathrm{w}$ raporcie:

w ciągu wszystkich pięciu lat badań BKL pracodawcy uznawali za najważniejsze - bez względu na zawód, do jakiego poszukiwali pracowników - trzy rodzaje kompetencji: samoorganizacyjne - związane z umiejętnościami takimi jak: zarządzanie czasem samodzielność, podejmowanie decyzji i przejawianie inicjatywy, odporność na stres i chęć do pracy; zawodowe - specyficzne umiejętności niezbędne do wykonywania zadań właściwych dla danego stanowiska pracy; interpersonalne - umiejętność kontaktowania się z ludźmi, bycia komunikatywnym, współpracy w grupie, a także rozwiązywania konfliktów międzyludzkich ${ }^{38}$.

Kwalifikacje, a także kompetencje językowe były rzadziej wskazywane przez pracodawców i zajęły odpowiednio 8. oraz 10. miejsce w zestawieniu

${ }^{36}$ Szkoła Główna Handlowa w Warszawie, Amerykańska Izba Handlu w Polsce, Ernst \& Young, Kompetencje i kwalifikacje poszukiwane przez pracodawców wśród absolwentów szkót wyższych wchodzacych na rynek pracy, Warszawa 2012, s. 9.

37 Tamże, s. 19.

${ }^{38}$ M. Kocór, A. Strzebońska, M. Dawid-Sawicka, Rynek pracy widziany oczami pracodawców, Warszawa 2015, s. 52. 
ogólnych wymagań kompetencyjnych zgłaszanych przez pracodawców szukających pracowników w latach 2010-2014 ${ }^{39}$.

Ponadto, w warunkach neoliberalnego przeedukowanego społeczeństwa ważne stają się również podczas oceny kandydatów do pracy, którzy mają takie same formalne kwalifikacje, czynniki subiektywne - intuicja pracodawcy oraz ogólne wrażenie (włącznie ze stylem ubierania i sposobem wysławiania się, a nawet profilem twarzy $)^{40}$. Zbyszko Melosik zauważa, iż „mamy tu więc swoisty "powrót do przeszłości«, kiedy to właśnie te zmienne odgrywały decydującą rolę"41. Również Anna Kokocińska na podstawie przeprowadzonych wywiadów z pracodawcami wywnioskowała, iż duże znaczenie przywiązują oni do dobrych manier oraz schludnego wyglądu zewnętrznego kandydata. Świadczą o tym między innymi słowa jednego z badanych, który przyznał, iż „bardzo miło, jeżeli ktoś umiał powiedzieć dzień dobry i przepraszam" ${ }^{42}$, inny z kolei wskazał, że liczy się wygląd oraz pierwsze wrażenie. Ponadto, dwójka pracodawców odwołała się do zasady: "Jak cię widzą, tak cię piszą" ${ }^{43}$.

W tym miejscu należy podkreślić, iż obecnie, pomimo że $w$ większości społeczeństw, także i w Polsce, wiodącą ideologią jest merytokracja, która zakłada, że sukces społeczny oraz zawodowy jednostek zależy od ich umiejętności, wykształcenia oraz edukacyjnych osiągnięćc ${ }^{44}$, to w praktyce we współczesnej rywalizacji na rynku pracy o atrakcyjne i dobrze płatne miejsca pracy znaczny wpływ ma pochodzenie społeczne jednostki decydujące o jej sposobie socjalizacji. Agnieszka Gromkowska-Melosik powołując się na L. Ashley, J. Durberley i D. Scholaris wyjaśnia, iż pracodawcy biorąc pod uwagę w procesie rekrutacji oprócz edukacyjnych kredencjałów, a także poziomu inteligencji (kognitywne kompetencje) określanego za pomocą testów psychometrycznych, właśnie opisane wyżej kompetencje miękkie, a także zachowanie i wygląd, oceniają w rzeczywistości kompetencje kulturowe kandydata oraz jego status społeczno-ekonomiczny ${ }^{45}$. Wspomniana autorka, odwołując się do pracy D.K. Browna, pisze o tym w następujący sposób:

\section{Tamże.}

40 Z. Melosik, Uniwersytet i społeczeństwo, s. 137.

41 Tamże.

42 A. Kokocińska, Społeczna wartość wyższego, s. 199.

43 Tamże, s. 198.

44 Por. m.in. D. Shifrer, Meritocracy, [w:] Sociology of Education: An A-to-Z Guide, red. J. Ainsworth, London 2013, s. 461; C.H. Kim, Y.B. Choi, How Meritocracy is Defined Today?: Contemporary Aspects of Meritocracy, Economics and Sociology, 2017, 10(1), s. 112.

45 L. Ashley, J. Durberley, D. Scholaris, A qualitative evaluation of non-educational barriers to the elite proffesions, London 2015, s. 23 podaję za: A. Gromkowska-Melosik, Edukacja, (nie)równość i rywalizacja. Teoretyczne interpretacje, [w:] Edukacja i społeczeństwo. Dynamika socjopedagogicznych konstrukcji, red. A. Gromkowska-Melosik, E. Grzesiak, J. Drozdowicz, M. Gierczyk, Poznań 2018, s. 20. 
współcześnie coraz częściej pracodawcy, oprócz dyplomu konkretnej szkoły wyższej i konkretnych kompetencji przydatnych w miejscu pracy, oczekują od kandydata "kulturowych dyspozycji przypisanych do danego stanowiska”, oceniają cechy osobiste $^{46}$.

Tak więc jednostki pochodzące $\mathrm{z}$ wyższych klas społecznych mają większe szanse, niż osoby z grup nieuprzywilejowanych, na spełnienie kryteriów doboru pracowników odnoszących się do aspektów behawioralnych oraz społecznych stosowanych przez współczesnych pracodawców.

Bez wątpienia, należy również wskazać, iż ważną obecnie rolę w uzyskaniu atrakcyjnej posady i odniesieniu sukcesu na rynku pracy jest posiadanie doświadczenia zawodowego oraz umiejętności praktycznych, co stanowi jedno z wymagań współczesnych pracodawców ${ }^{47}$. Pracodawcy oprócz odpowiedniego wykształcenia wymagają średnio od potencjalnego pracownika 1,5 roku stażu pracy ${ }^{48}$. W sytuacji inflacji dyplomu akademickiego oraz przeedukowania społeczeństwa niezwykle ważne jest zatem stawianie pierwszych kroków na rynku pracy już podczas studiowania, gdyż w wielu przypadkach doświadczenie zawodowe stanowi warunek bezwzględny podczas ubiegania się o daną posadę. Tak więc już w procesie studiów jednostka przyjmuje zgodnie z duchem neoliberalizmu odpowiedzialność za swoje losy zawodowe, niejako paralelnie do procesu studiowania.

Podsumowując powyższe rozważania, należy wskazać, iż mamy obecnie do czynienia z reorganizacją oczekiwań wobec tożsamości osób nowo przyjmowanych do pracy ze strony pracodawców. O ile w przeszłości oczekiwano osoby doskonale i na zawsze pasującej do określonego stanowiska czy zawodu, obecnie pracodawcy poszukują jednostek o „elastycznych" tożsamościach. Ta otwartość dotyczy zarówno rozszerzenia spektrum kompetencji, jak i cech psychospołecznych oraz intelektualno-kognitywnych. Pracownik ma więc posiadać elastyczny zestaw kompetencji i elastyczną tożsamość po to, aby zmieniać się i adaptować do oczekiwań pracodawcy oraz zmian strukturalnych $\mathrm{w}$ miejscu pracy. W przeszłości schemat kariery zawodowej był jednoznaczny. Można go przedstawić za pomocą następujących etapów: wybór kierunku studiów, proces studiowania, w czasie którego zdobywa się kwalifikacje oraz kompetencje, przyjmowanie do pracy (często na warunkach jedno miejsce i jeden lub kilku kandydatów), przechodzenie przez kolejne

${ }^{46}$ D.K. Brown, The social sources of educational credentialism: status cultures, labor markets and organizations, Sociology od Education, 2001, Extra Issue, 74, s. 20 podaję za: A. Gromkowska-Melosik, Edukacja, (nie)równość, s. 20.

${ }^{47}$ Por m.in. G. Wronowska, Oczekiwania pracodawców wobec absolwentów szkół wyższych w Polsce jako przyktad bariery wejścia na rynek pracy, Prace Naukowe Uniwersytetu Ekonomicznego we Wrocławiu, 2013, 305, s. 862.

${ }^{48}$ M. Kocór, A. Strzebońska, M. Dawid-Sawicka, Rynek pracy widziany, s. 9. 
stopnie awansu zawodowego we względnie stabilnym miejscu pracy. Obecnie sytuacja jest zupełnie odmienna, co wynika między innymi z opisanej $\mathrm{w}$ artykule zwiększonej rywalizacji o miejsce zatrudnienia, dużej mobilności pracowników i restrukturalizacji firm oraz trajektorii kariery, które - zgodnie z ideologią neoliberalizmu - nieraz są alternatywne wobec siebie lub ze sobą sprzeczne. Myliłby się jednak ktoś, kto zakładałby, iż pracodawca odczuwa odpowiedzialność za losy pracownika w czasie jego kariery zawodowej lub choćby jest paternalistycznym zwierzchnikiem. Współcześnie w środowisku korporacyjnym to dana osoba, zgodnie z założeniami neoliberalizmu, jest odpowiedzialna zarówno za swoje cechy "tu" $\mathrm{i}$,"teraz", jak i za swoje cechy osobowościowe, które muszą dawać jej możliwość odpowiedzi na oczekiwania w bardzo szerokim spektrum kryteriów. Podlega tutaj rekonstrukcji kryterium efektywności, gdyż o ile w przeszłości odnosiła się ona do doskonałości do realizacji konkretnych zadań, to obecnie związana jest także ze zdolnością do permanentnej adaptacji i rekonstrukcji samego siebie. Odchodzi do przeszłości szary urzędnik, który stabilnie funkcjonował $\mathrm{w}$ jednym miejscu pracy niekiedy przez dekady. Współcześnie zmieniła się także rola i hierarchia pozostałych kryteriów doboru pracowników. W wielu przypadkach formalne kwalifikacje stanowią, jak to było wspomniane wcześniej, absolutne minimum $\mathrm{w}$ procesie rekrutacji, a pracodawców prócz formalnych kredencjałów interesuje aspekt behawioralny oraz osobowościowy potencjalnych kandydatów. Nie bez powodu coraz częściej wykorzystują oni takie metody rekrutacyjne jak, assessment center ${ }^{49}$ czy testy kompetencji ${ }^{50}$, dzięki czemu możliwe jest sprawdzenie zarówno wiedzy, umiejętności, jak i postaw osoby ubiegającej się o pracę ${ }^{51}$.

W ostatecznej konkluzji należy bez wątpienia podkreślić, iż rynek pracy stawia obecnie przed osobami poszukującymi wymarzonej posady cały szereg wymagań, a wszystko wskazuje na to, że w kolejnych latach będą pojawiać się kolejne, następne "nowe" pożądane przez pracodawców kompetencje, próby wskazania których już teraz są podejmowane przez teoretyków oraz badaczy rynku pracy i określane mianem kompetencji przyszłości ${ }^{52}$.

${ }^{49}$ Por. m.in. International Taskforce on Assessment Center Guidelines, Guidelines and Ethical Considerations for Assessment Center Operations, Journal of Management, 2015, 41(4), s. 1245.

${ }^{50}$ W. Łozowiecka, Kompetencyjno-działaniowy paradygmat edukacji zawodowej we wspótczesnych warunkach pracy, Szkoła - Zawód - Praca, 2012, 4, s. 48.

${ }^{51}$ Por. m.in. T. Oliver i in., Interpersonal Dynamics in Assessment Center Exercises: Effects of Role Player Portrayed Disposition, Journal of Management, 2016, 42(7), s. 1993; A. Lipińska-Grobelny, Ośrodek oceny (Assessment Center), Zarządzanie Zasobami Ludzkimi, 2005, 3-4, s. 102-103.

${ }_{52}$ Institute for the Future for the University of Phoenix Research Institute, Future Work Skills 2020, s. 8-12, http://www.iftf.org/uploads/media/SR-1382A_UPRI_future_work_skills_sm.pdf, [dostęp: 16.04.2019]. 


\section{BIBLIOGRAFIA}

Bourdieu P., Distinction: A Social Critique of the Judgement of Taste, Harvard University Press, Cambridge 1984.

Delsen L., Exit Polder Model?: Socioeconomic Changes in the Netherlands, CT: Praeger, Westport 2002.

Domański H., Stratyfikacja a system społeczny w Polsce, Ruch Prawniczy, Ekonomiczny i Socjologiczny, 2009, 2.

Ecorys, Absolwent na rynku pracy - poradnik dla Ucznia i Nauczyciela, https:/ /ckziunr3.pl/ wp-content/uploads/KCDZ/doradz15.pdf [dostęp: 09.04.2019].

Grodziński M., Korposzczury, prawdziwi wyklęci, 2016, http://wyborcza.pl/magazyn/ 1,124059,19886789,korposzczury-prawdziwi-wykleci.html [dostęp: 08.04.2019].

Gromkowska-Melosik A., Edukacja i (nie)równość społeczna kobiet. Studium dynamiki dostępu, Oficyna Wydawnicza Impuls, Kraków 2011.

Gromkowska-Melosik A., Edukacja, (nie)równość i rywalizacja. Teoretyczne interpretacje, [w:] Edukacja i społeczeństwo. Dynamika socjopedagogicznych konstrukcji, red. A. Gromkowska-Melosik, E. Grzesiak, J. Drozdowicz, M. Gierczyk, Wydawnictwo Naukowe UAM, Poznań 2018.

InstitutefortheFuturefor theUniversity ofPhoenixResearchInstitute,FutureWorkSkills2020, http://www.iftf.org/uploads/media/SR-1382A_UPRI_future_work_skills_sm.pdf, [dostęp: 16.04.2019].

International Taskforce on Assessment Center Guidelines, Guidelines and Ethical Considerations for Assessment Center Operations, Journal of Management, 2015, 41(4).

Kim C.H., Choi Y.B., How Meritocracy is Defined Today?: Contemporary Aspects of Meritocracy, Economics and Sociology, 2017, 10(1).

Kisińska J., Homo corporaticus, czyli przewodnik przetrwania w korporacji, https:// onepress. $\mathrm{pl} /$ ksiazki/homo-corporaticus-czyli-przewodnik-przetrwania-w-korporacji-joanna-krysinska,jaszko.htm\#format/e [dostęp: 08.04.2019].

Knap-Stefaniuk A., Wspótczesny rynek pracy - oczekiwania pracodawców w zakresie kompetencji kandydatów, [w:] Człowiek wobec wyzwań współczesnego rynku pracy, red. S. Ciupka, A. Knap-Stefaniuk, A. Sapiński, Wydawnictwo SCRIPTUM, Kraków 2015.

Kocór M., Strzebońska A., Dawid-Sawicka M., Rynek pracy widziany oczami pracodawców, Polska Agencja Rozwoju Przedsiębiorczości, Warszawa 2015.

Kokocińska A., Spoteczna wartość wyższego wyksztatcenia, Wydawnictwo Naukowe UAM, Poznań 2015.

Lipińska-Grobelny A., Ośrodek oceny (Assessment Center), Zarządzanie Zasobami Ludzkimi 2005, nr 3-4.

Łozowiecka W., Kompetencyjno-działaniowy paradygmat edukacji zawodowej we wspótczesnych warunkach pracy, Szkoła - Zawód - Praca, 2012, 4.

Maikowski D., Jak okiełznać "Mordor"? 12 zasad przetrwania w korporacji, https://praca.interia.pl/news-jak-okielznac-mordor-12-zasad-przetrwania-wkorporacji,nId,1671792\#utm_source=paste\&utm_medium=paste\&utm_campaign=chrome, 2015 [dostęp: 08.04.2019].

Marques A.P., Unequal Itineraries for Graduates: A Typology of Entrance into Labour Market, Academic Journal of Interdisciplinary Studies, 2015, 4 (1S2).

Martkowska K., Molasy M., Społeczna odpowiedzialność uczelni w procesie ksztatcenia przyszłych elit, [w:] Społeczna odpowiedzialność uczelni, red. K. Leja, Wydawnictwo Politechniki Gdańskiej, Gdańsk 2008. 
McGuinness S., Overeducation in the Labour Market, Journal of Economic Surveys, 2006, 20(3).

Melosik Z., Uniwersytet i społeczeństwo. Dyskursy wolności, wiedzy i władzy, Oficyna Wydawnicza Implus, Kraków 2009.

Melosik Z., Kultura popularna i tożsamość młodzieży. W niewoli władzy i wolności, Oficyna Wydawnicza Impuls, Kraków 2013.

Oliver T., Hausdorf P., Lievens F., Conlon P., Interpersonal Dynamics in Assessment Center Exercises: Effects of Role Player Portrayed Disposition, Journal of Management, 2016, 42(7).

Rozmus A., Edukacja akademicka w perspektywie krytycznej. Studenci wobec neoliberalnej polityki kształcenia w szkole wyższej, Oficyna Wydawnicza Impuls, Kraków - Rzeszów 2018.

Shifrer D., Meritocracy, [w:] Sociology of Education: An A-to-Z Guide, red. J. Ainsworth, Sage, London 2013.

Sobocka-Szczapa H., Dobór pracowników - decyzja strategiczna firmy, Zeszyty Naukowe Politechniki Śląskiej, 2014, 1905.

Sobocka-Szczapa H., Zarządzanie kompetencjami pracowników a kapitat intelektualny organizacji, Prace Naukowe Uniwersytetu Ekonomicznego we Wrocławiu, 2017.

Szaban J.M., Rynek pracy w Polsce i w Unii Europejskiej, Wydanie 2, Wydawnictwo Difin, Warszawa 2016.

Szkoła Główna Handlowa w Warszawie, Amerykańska Izba Handlu w Polsce, Ernst \& Young, Kompetencje i kwalifikacje poszukiwane przez pracodawców wśród absolwentów szkót wyższych wchodzacych na rynek pracy, Warszawa 2012.

Tamondong K., Surviving The Corporate Jungle: 8 Unwritten Rules To Guide Your Success, 2014, https://www.elitedaily.com/money/surviving-the-corporate-jungle-8-unwritten-rules-to-guide-your-success [dostęp: 08.04.2019].

Ueno K., Krause A., Overeducation, perceived career progress, and work satisfaction in young adulthood, Research in Social Stratification and Mobility, 2018, 55.

Wronowska G., Oczekiwania pracodawców wobec absolwentów szkót wyższych w Polsce jako przykład bariery wejścia na rynek pracy, Prace Naukowe Uniwersytetu Ekonomicznego we Wrocławiu, 2013, 305. 